\title{
Keistimewaan Penataan Ruang Menurut Peraturan Daerah Istimewa Provinsi Daerah Istimewa Yogyakarta
}

\author{
Muhammad Iqbal'), Yunita Elianda'), Ali Akbar ${ }^{1)}$, Nurhadiyanti'2) \\ 1)Magister Ilmu Pemerintahan, Program Pascasarjana, Universitas Muhammadiyah \\ Yogyakarta, Indonesia \\ 2) Program Studi Ilmu Pemerintahan, Sekolah Tinggi Ilmu Sosial dan Ilmu Politik \\ Raja Haji Tanjungpinang, Indonesia
}

\begin{abstract}
Abstrak
Yogyakarta sebagai salah satu daerah di Indonesia yang diberikan hak istimewa oleh pemerintah pusat sehingga dalam bentuk pemerintahannya menjadi berbeda dengan daerah lainnya. Bukan hanya bentuk pemerintahan akan tetapi pada aspek-aspek lain bahkan sampai pada penataan ruang daerah. Penelitian ini ingin memberikan gambaran mengenai keistimewaan penataan ruang yang ada di Yogyakarta yang tertuang dalam peraturan daerahnya. Untuk metode yang digunakan dalam menganalisi hasil penelitian ini menggunakan metode penelitian kuantitatif deskriptif. Hasil temuan dalam penelitian ini adalah bahwa keistimewaan dari Kota Yogyakarta yang lain yaitu terdapat satuan ruang strategis yaitu adanya Satuan Ruang Tanah Kadipaten dan Satuan Ruang Tanah Kadipaten. Dalam pengelolaan tata ruang tersebut di tuangkan dalam Perda No. 2 Tahun 2010 yang kemudain diundangkan, diberlakukan Undang Undang tersebut, diharapkan dapat memberikan kesejahteraan terhadap hak hak masyarakat dan dalam bentuk faktanya nyatanya masih belum berjalan dengan baik. Berbagai faktor faktor yang membuat hal tersebut terjadi diantaranya masih adanya pembangunan perkotaan yang tidak menuruti Undang Undang yang berlaku. diantaranya pembangunan mall dan hotel yang tidak teratur. Seperti Sleman city mall yang pembangunanya lebih dulu dilakukan sebelum peraturan tersebut berlaku.

Kata Kunci: Perda, Tata Ruang, Keistimewaan.
\end{abstract}

\begin{abstract}
Yogyakarta as one of the regions in Indonesia that have been given special rights by the central government so that the form of government is different from other regions. Not only in the field of government, but in other aspects to the regional spatial planning. This research wants to give an overview of the special spatial planning in Yogyakarta as stipulated in the regional regulation. For the method used in analyzing the results of this study using descriptive quantitative research methods. The findings in this study are about Yogyakarta City Privileges which is one of the strategic spaces owned by the Duchy Land Space Unit and Duchy Land Space Unit. In managing the spatial plan mentioned above in Perda No. 2 of 2010 which was then enacted, the enactment of this Act is expected to assist the rights of the community and, in fact, is still not going well. Various factors that make this still happen exist because of development that is not following applicable laws. Development malls and hotels are irregular. Like the Sleman city mall, the construction was done before the regulation took effect.
\end{abstract}

Keywords: Local Regulation, Spatial Planning, Privileges 


\section{PENDAHULUAN}

Daerah Istimewa Yogyakarta merupakan salah satu daerah di Indonesia yang diberikan hak istimewa dari Negara Indonesia dalam penyelenggaraan urusan di Pemerintahan. Menurut Undang-Undang Dasar 1945 dalam mengatur urusan keistimewaan disebutkan "Kewenangan Istimewa adalah wewenang tambahan tertentu yang dimiliki Daerah Istimewa Yogyakarta selain wewenang sebagaimana ditentukan dalam Undang-Undang tentang pemeriintahan daerah". Keistimewaan di dalam struktur pemerintah yaitu terletak di pengangkatan kepala daerah dan wakil daerahnya. Sri Sultan dan Paku Alam adalah sebagai pemegang tahta yang kemudian tahta tersebut akan terus diturunkan kepada generasi berikutnya. Kepala Daerah dan Wakil Kepala Daerah di Yogyakarta memiliki wewenang dan tugas seperti daerah yang lainnya, dan ditambah dengan penyelenggaraan urusan pada daerah keistimewaan.

Menurut Undang-Undang nomor 13 tahun 2013 tentang keistimewaan yogyakarata menyebutkan "Terdapat 5 pembagian yang bisa diatur secara otonom oleh DIY, kelima ranah tersebut diatur pada peraturan daerah yang disebut perdais (perda istimewa )". Hal tersebut dapat dijadikanya tata ruang sebagai salah satu point subtansi keistimewaan, penataan ruang DIY berpeluang untuk diperkuat sesuai dengan karakter lokal, adapun tujuan penataan ruang yaitu untuk mengembalikan, memeperbaiki, menegmbangkan serta menjadikan nilai dan penggunaan ruang DIY. Penyusunan rancangan perdais tata ruang mengacu pada UU No. 26 tahiun 2007 tentang penataan tata ruang. Dengan demikian penyususnan rencana tata ruang (RTR) akan mengikuti tingkatan sesuai yang tercantum pada undang tersebut.

Tanah sultan dan tanah pakualaman akan digunkan sebagai daerah strategi pada RTRW DIY yang kemudian akan menjadi RTBL dan RDTR tentang wilayah strategi tanah kesultanan dan Kawasan strategis tanah kesultanan dan kawasan, diantara Kawasan-kawasan yang akan ditetapkan untuk kawasan strategis adalah kawasan kraton, tamansari, dan tanahtanah magersari. Dalam ranah implementasi pada keistimewaan tata ruang 
DIY akan menunjukkan kerangka umum umum kebijakan tata ruang pada tanah SG dan PAG arahan pengelolaaan dan pemanfaat tanah non SG dan non PAG.

Tata ruang merupakan wujud dari struktur ruang dan pola ruang,sementara itu struktur ruang yaitu pusat pemukiman dan jaringan prasarana dan sarana yang berfungsi sebagai pendukung kegiatan social ekonomi masyarakat". Tata ruang merupakan rencana untuk menata kemabali sitem tata ruang terbengkalai ataupun yang kurang baik menjadi baik, bagus dan berguna untuk masyarakat yang berada diwilayah daerah tersebut. Adapun menurut Eko Budiharjo, 1997 dalam buku Adon Nasrullah, 2015 tata ruang menjelaskan bahwa " Keterkaitan dan keserasian tata guna lahan, air, udara serta alokasi sumber daya melalaui koordinasi dan upaya penyelesaian konflik antar kepentingan yang berbeda".

Selain itu adapun beberapa keistimewaan pada bidang bidang tertentu karena ada 3 subtansi yang dimiliki DIY sehingga melahirkan beberapa bidang yang memiliki keistimewaan serta tidak ada pada daerah-daerah / wilayah yang lain. Adapun keistimewaaan pada bidang tata ruang yaitu sultan memiliki wewenang dan kadipaten dalam tata ruang untuk pengelolaan dan pemanfaatan tanah kesultanan dan tanah kadipaten.

\section{METODE PENELITIAN}

Dalam Penelitian ini jenis penelitian yang digunakan metode kuantitatif dan deskriptif yang menggunakan berbagai data yang terdapat di lapangan dengan jangka waktu tertentu. Penelitian dengan menggunakan metode kuantitatif yang menganalkan deskriptif secara kuantitatif untuk membuat gambaran faktual dan akurat mengenai fakta fakta yang akan diselidiki.

Penelitian menggunakan metode ini menggunakan teknik pengumpulan data dengan dan wawancara dan dokumentasi dengan salah satu staff atau ketua dari dinas Tata Ruang DIY Ada beberapa teknik pengumpulan data yang digunakan dalam penelitian ini, diantaranya : 
- Wawancara

Wawancara merupakan sebuah proses untuk mendapatkan sebuah keterangan atau informasi yang sesuai dengan topik penelitian. Wawancara yang digunakan dalam penelitian ini adalah wawancara tertutup dengan cara tanya jawab tatap muka antara peneliti dengan objek peneliti. Wawancara adalah keterangan yang diberikan objek peneliti untuk memperoleh suatu keterangan, memastikan fakta yang terjadi di lapangan, memperkuat hipotesis yang sudah diramalkan, dan mengenali lebih dalam tentang topik penelitian yang diteliti. Wawancara tertutup yaitu wawancara yang menggunakan pertanyaan yang sudah dirancang sejak awal persiapan penelitian sehingga kemungkinan yang didapat yaitu jawaban yang sangat terbatas dan sudah terstruktur dalam pertanyaan.

- Dokumentasi

Dokumentasi merupakan hal yang yang perlu dan penting untuk kelangsungan bagaimana kita mendapatkan sebuah informasi mengenai gambar dan vidio untuk penelitian, oleh karna itu dokumentasi harus ada pada dalam sebuah teknik pengumpulan data. karena dengan adanya dokumentasi maka akan mempermudah para peneliti untuk mendapatkan objek yang diteliti serta akan mempermudah peneliti.

\section{PEMBAHASAN}

a) Paparan Keistimewaan Tata Ruang Daerah Istimewa Yogyakarta.

Kota Yogyakarta merupakan salah satu kota yang unik dan istimewa, lokasi kota yang dihapit oleh sungai dan situs situs budaya Yogyakarta yang unik membuat kota Yogyaakaarta menjadi sangat istimewa. Lokasi yang dihapit oleh gunung dan Lautan Hindia menambah nilai keistimewaan dari Kota Yogyakarta. Menurut Reviaanto dan Sri (2008) yang dikutip oleh Suryanto, dkk (2015) menjelaskan bahwa lokassi Kota Yogyakarta dinilai menjadi kota yang istimewa karena telah menduduki syarat syarat sebagai ibu kota kerajaan. Keistimewaan Kota Yogyakarta dapat menjadi peluang yang besar dalam mencapai berbagai potensi yang dimiliki oleh Pemerintah Daerah Daerah Istimewa Yogyakarta terutama terhadap tata ruang yang 
ada di DIY. Hak Istimewa yang didapatkan Kota Yogyakarta berasal dari perjuangan pada masa penjajahan dahulu yang mana Kota Yogyakarta telah mempertahankan dan menjaga keutuhan NKRI. Hak istimewa tersebut tidak akan jauh dari sejarah yang dimiliki oleh Yogyakarta.

Menurut Pasal 1 Undang Undang Nomor 13 Tahun 2012 tentang keistimewaan DIY menjelaskan bahwa sejarah dan hal asal usul yang dimiliki DIY sesuai dengan Undang Undang Dasar dengan melihat keistimewaan sebagai kedudukan hukum. Menueurt Pasal 7 Undang Undang Nomor 13 Tahun 2012 menjelaskan bahwa kewenangan dari urusan urusan keistimewaan diantaranya 1) Pengisian Jabatan, wewenang dan tugas Gubernur dan wakil gubernur 2)Kelembagaan Pemerintah Daerah DIY 3) Keistimewaan Budaya 4) Pengelolaan Pertanahan 5) Tata Ruang DIY. Keistimewaan yang diurus merupakan bentuk dari keistimewaan kedudukan hukum untuk mengatur dan mengurus kewenangan istimewa tersebut.

Menurut Peraturan Derah Istimewa Yogyakarta Nomor 2 Tahun 2017 disebutkan bahwa keistimewaan dari Kota Yogyakarta yang lain yaitu terdapat satuan ruang strategis yaitu adanya Satuan Ruang Tanah Kadipaten dan Satuan Ruang Tanah Kadipaten. Pengelolaan tanah kadipaten dan tanah kasultananakan diserahkan ke administratif masing masing daerah dengan persetujuan Sultan dan Pakualaman. Nilai keistimewaan yang dimiliki oleh Kota Yogyakaarta baik awasan tanah kasultanan dan tanah kadipaten maupun satuan ruang yang lainnya akan diprioritaskan Pemerintah Daerah bagaimana caranya kawasan satuan ruang tersebut digunakan secara makssimal sesuai dengan Peraturan Daerah Istimewa. Pemrioritasan kawasan satuan ruang tersebut akan berpengaruh terhadap budaya, kelestarian lingkungan, serta kepentingan sosial. Penataan ruang Keistimewaan Daerah Istimewa Yogyakarta merupakan salah satu dari sistem proses perencanaan dan penataan Tata Ruang maupun pengendalian pemanfaatan kawasan satuan strategis tersebut. Berikut gambar bagian bagian kawasan kadipaten dan kasultanan. 


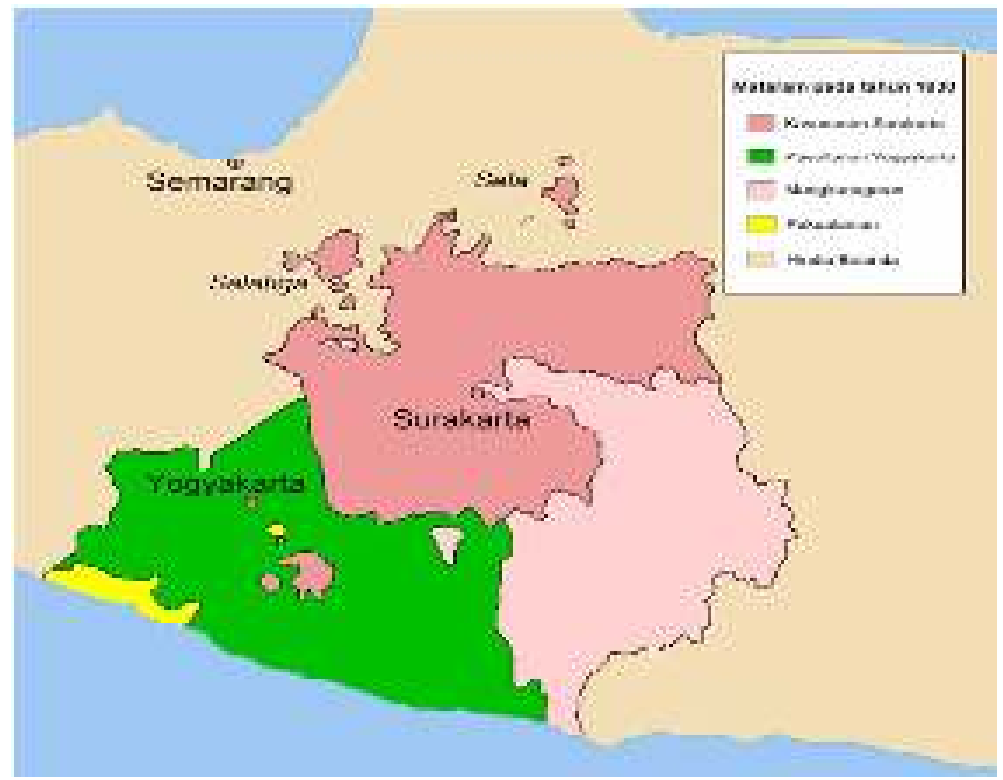

Sumber : $\underline{\text { https://images.app.goo.gl/gYv5WSsiqSuMUiBA8 }}$

Menurut Musliichah (2017) penataan ruang dilakukan berdasarkan filosofi yang ada diantaranya :

"1)Harmoni, Kelestarian lingkungan, sosial ekonomi (hamemayu hayuning bawana); 2) Spirituql transenden (sangkan paraning dumadi); 3) Humanisme, asas kepemimpinan demokratis(manunggaling kawula lan gusti); 4) Kebersamaan (tahta untuk rakyat); 5)Harmonisasi lingkungan (poros imajiner laut seltan-kraton -gunung merapi); 6)Ketaatan historis(sumbu filosofis Tugu-Kraton-Panggung Krapyak); 7)Filosofi inti kota (catur gatra tunggal); dan 8) Delineasi spasial (pathok negara)"

Hal yang menarik untuk dibahas yaitu keistimewaan filosofis ketatanan historis yang sangat unik di Daerah Istimewa Yogyakarta yaitu adanya sumbu filosofis tata ruangyang membujur lurus selatan sampai utara dengan makna historis yang kuat. Elemen elemen ruang bangunan TuguKraton-Panggung Karpyak menjadi konfigurasi ruang yang unik. Sumbu yang dijelaskan tersebut sebagai gambaran konsep dari mikrosmos yang artinya jika ditarik secara garis besar konsep tersebut ada garis imajiner 
Selatan sampai Utara yaitu dari laut selatan sampai Gunung Merapi. Berikut gambar imajiner yang dilihat secara garis besar membujur lurus.
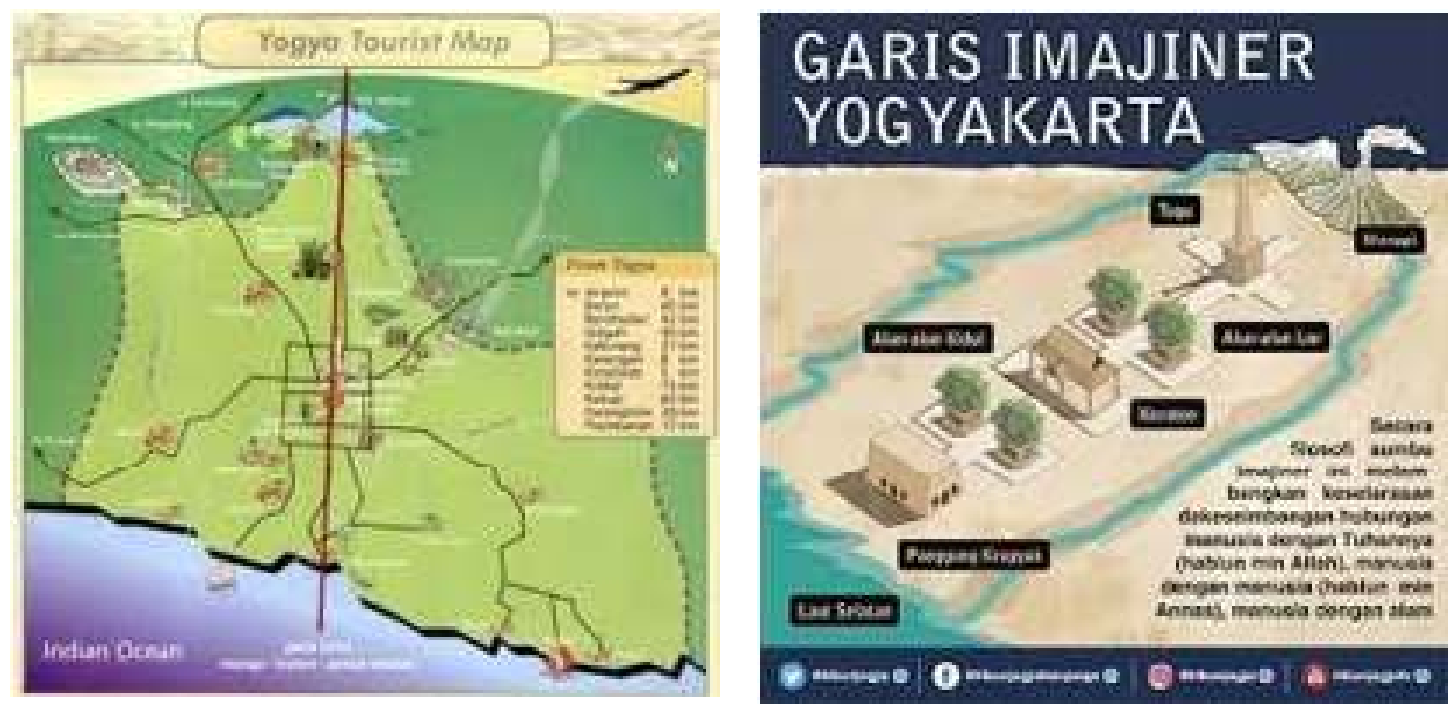

Sumber : $\quad$ https://images.app.goo.gl/Vr8SYbkCBxkfJn7r7 dan https://images.app.goo.gl/iX9LKNDqFcVvYC1r7

Dari analisis gambar diatas makna dari filosofis dari Panggung Krapyak ke utara menggambarkan konsep Spiritual transenden yang diartikan sebagai darimana asal muasal manusia dan arahan kemana tujuan manusia. Dimaulai dari awal mula manusia dari embrional kemuudian lahir berproses berkembang sampai dewasa dan menikah. Panggung krapyak di utara memiliki kampung bernama kampung Mijen yang melambangkan benih benih manusia. Makna sebaliknya juga berlaku dari arah Tugu ke selatan menggambarkan perjalanan manusia sampai kembali kepada Tuhannya. Tugu Golong Gilig memiliki arti bersatunya karsa, rasa, dan cipta yang melandasi kesucian hati manusia. Selain itu pasar Beringharjo dan kepatihan menggambarkan godaan harta dan kekuasaan yang harus dihindari manusia. Keunikan tata ruang dengan sumbu filosofis yang kuat di Daerah Istimewa Yogyakarta layak menjadi warisan budaya dunia UNESCO karena tata kota yang unik dan jarang ditemukan dibelahan dunia. 
b) Kebijakan Tata Ruang dalam Peraturan Daerah Istimewa.

Kebijakan yang dilakukan dari dinas tataruang Daerah Istimewa Yogyakarta berfokus pada membuat landasan landasan peraturan yang terkait dengan pemanfaatan ruang di satuan ruang strategis. Mengingat bahwa Peraturan Daerah Nomor 2 Tahun 2010 mengenai dengan RTRW DIY tahun 2009-2029 dianggap sudah tidak relevan dengan situasi di DIY, oleh karena itu Peraturan Derah harus seceptnya diganti dengan membandingkan kondisi yang sedang dihadapi wilayah DIY. Menurut Qoyin sebagai seksi pengaturan tataruang Daerah Istimewa Yogyakarta menjelaskan bahwa "Banyak Dinamika dilapangan yang terjadi sejak Perda No. 2 Tahun 2010 diundangkan, sehingga terjadi perubahan yang tidak sesuai lagi dengankonten Peraturan Daerah dan aturan tersebut dapat mengisyaratkan jika perubahan konten lebih dari $20 \%$ maka perlu dibuat Perda yang baru".

Ada berbagai peristiwa yang membuat sisim tata ruang di Yogyakarta sebelum diundangkannya Peraturan Daerah Nomor 2 Tahun 2010 diantaranya terjadinya erupsi gunung Merapi , adanya Peraturan Daerah Istimewa DIY, dan berbagai kebijakan kebijakan strategis nasional dengan adanya pembangunan pembangunan yang berlokasi di DIY. Studi kasus yang akhir akhir ini hangat dibicarakan dan masih baru yaitu pembangunan bandara Yogyakarta Internasional Airport, adanya perubahan fungsi lahaan yang awalnya lahan tersebut dijadikan sebagai mata ppencaharian massyarakat sekarang dibangunnya bandara membuat laahan masyarakat. diharapkan Peraturan Daerah yang baru harus menyesuaikan dengan semua dinamika dinamika yang terjadi di daerah tersebut dan menjadi payung hukum bagi semua orang yang memiliki kepentingan dalam pelaksanaan tata ruang wilayah DIY.

Ruang strategis keistimewaan basisnya yang menjadi inti adalah spot tanah milik kasultanan dan kadipaten kemudian perlu diatur dari aspek sosial budaya. Tataruang tidak hanya mengurusi tanah dan pemanfaatannya bagaaimaana. Contoh tanah malioboro yang sebagian besar dimiliki oleh tanah kasultanan dan kadipaten seperti kepatihan. Banyak tanah juga yang 
bukan milik kasultanan dan kadipaten tapi bagaimana kawasan pemanfaatan jenis aktivitas yang dilakukan ditanah tersebut tataruang yang mengatur.

Masyarakat harus bersikap berani dan tegas dalam menghadapi pihak pihal yang memiliki hak atas tanah kadipaten dan kasultanan. Hal ini disampaikan oleh keraton Yogyakarta, karena adanya kejadian di lapangan bahwa terdapat keputusan yang trbit yang dikeluarkan oleh kerbat keraton. Dalam kasus ini, masyarakat jangan takut untuk membela sesuatu yang bukan hak mereka di tanah kasultanan-kadipaten dan tidak menanggapi siapapun yang menganggap bahwa mereka punya hak atas tanah kasultaan dan kadipaten. Masyarakat harus menolak meski yang bersangkutan tmengaku sebagai kerabat Sultan dan jangan sampai dilayani. Kasultanan dan Kadipatenlah yang memiliki hak atas tanah tanah tersebut, Lembaga Kasultanan juga menegaskan bahwa tanah kasultanan bukanlah milih pribadi hanya saja kasultananlah memiliki hak untuk mengelola dan memanfaatkan tanah tanah tersebut agar tidak disalahgunakan untuk pembangunan yang "ngawur". Diperlukannya pengajuan perizinan pemanfaatan tanah kasultanan harus disetujui oleh Sri Sultan. Hal ini menjadi salah satu kasus yang harus diperhatikan, seharusnya perlu ada tindakan atau langkah hukum kepada pihak yang menerbitkan dan memalsukan sertifikaat dengan menggunakan nama tanah kasultanan.

Yogyakarta sebagai daerah dengan potensi pariwisata merupakan daerah tujuan untuk wisatawan baik local maupun mancanegara untuk datang melihat potensi-potensi pariwisata yang ada di Yogyakarta. Pada umumnya para wisatawan yang datang ke Yogyakarta melihat beberapa bangunanbangunan bersejarah, seperti tamansari, kraton, candi Borobudur, candi Prambanan, dan lain-lain. Seiring banyaknya wisatawan yang datang ke Yogyakarta semakin banyak pula peluang bisnis untuk memenuhi kebutuhan para wisatawan, Yogyakarta sebagai daerah yang strategis juga di gunakan sebagai tempat conferensi pertemuan-pertemuan. Banyak juga para investor yang melirik untuk berinvestasi di Yogyakarta dan para investor berkeinginan untuk membangun sebuah hotel maupun ingin 
memiliki perusahaan yang berada di Yogyakarta. Maka dari itu banyak penananam modal dan investor yang membangun hotel dan mall di Yogyakarta.

Hampir setiap tahun pembangunan hotel di daerah yang dekat dengan tempat wisata mengalami pertumbuhan pembangunan hotel, sehingga pembanguan hotel tidak bisa terelakkan karena semakin bnyaknya para wisatawan ke Yogyakarta. Setiap tahunya hamper terdapat berapa hotel baru di Yogyakarta menurut data Badan Pusat Statistik (BPS) Daerah Istimewa Yogyakarta jumlah hotel yang berada di kawasan DIY hingga awal 2018 tercatat 517 hotel. Sebagai daerah yang memiliki banyak hotel dan banyak pula mall serta banyaknya warga yang menolak mengenai bangunan-bangunan baru, sebagai pihak yang manampung aspirasi masyarakat pemerintah provinsi Daerah Istimewa Yogyakarta pada akhirnya membuat kebijakan baru mengenai pengendalian hotel yang tertuang dalam perturan walikota nomor 77 tahun 2013. Banyaknya bangunan hotel dan mall yang menjulang tinggi, dan hal tersebut dapat mengganggu jalur penerbangan pada akhirnya pemerintah provinsi DIY melahirkan kebijakan baru mengenai peraturan bahwasanya pendirian banguan dengan ketinggian lebih dari 32 meter harus seizin walikota dan komandan landasan udara Adi Sucipto.

Kebijakan ini diatur pada pasal 14 ayat 1 dalam Perdais, mengenai "pemanfaatan ruang yang diperoleh pada satuan ruang strategis sumbu filosofi, yang berbunyi ketinggian bangunan paling tinggi delapan belas (18) meter pada area yang berjarak enam puluh meter (60) meter diukur dari batas ruang milik jalan" pada contohnya seperti pembangunan jalan mulai dari perempatan depan kantor post pusat (dalam kawasan jalan malioboro) hingga jalan tugu. Ketinggian bangunan paling tinggi 18 (delapan belas) meter pada area yang berjarak 60 (enam puluh) meter diukur dari batas ruang milik jalan" dan bangunan cagar budaya ketinggian bangunan juga diperhitungka, bangunan dikanan dan kiri jalan tersebut maksimal 18 (delapan belas) meter dengan kedalaman dari garis batas luar ruang milik jalan (rumija) yakni dengan ketinggian 60 (enam puluh) meter hal ini 
sudah tercermin pada pasal 14 ayat 1 nomor 2 dan 3 yang berbunyi "ketinggian bangunan paling tinggi 18 (delapan belas) meter pada area yang berjarak 60 (enam puluh) meter diukur dari batas ruang milik jalan” serta bangunan baru menggunakan gaya arsitektur bangunan berciri khas Yogyakarta dan memenuhi ketentuan untuk memebentuk sudut $45^{\circ}$ (empat puluh lima derajat) dari batas jalan. Bangunan-bangunan arsitektur yang berada dikawasan daerah pinggiran jalan malioboro yang menjadi bangunan sejarah tidaklah dihancurkan karena hal tersebut merupakan bangunan peninggalan sejarah guna untuk memeperkenalkan kepada wisatawan hasil jajahan bangsa asing terhadap bangsa Indonesia.

Selain itu untuk sebelah bagian belakang/dalam harus lebih dari 60 (enam puluh) meter dari garis batas luar rumija / ruang milik jalan dan diperbolehkan untuk membangun bangunan yang lebih tinggi dari bangunan yang berada di depan banguanya, dengan memebentuk sudut 45 (empat puluh lima derajat) dari ketinggian yang sudah di tentukan dan jika keinginan lain tersebut dikehendaki sudut pandang $45^{\circ}$ ( empat puluh lima derajat) harus ada persetujuan dari walikota Yogyakarta dengan maksimal ketinggian 32 (tigapuluh dua meter). Ini lah yang pada akhirnya membedakan daerah Istimewa Yogyakarata dari pada daerah lainya.

Dalam hal ini budaya juga menjadi salah satu acuan guna sebagai keistimewaan penanda tata ruang yang berada di daerah Yogyakarta. Pada dasrnya ada menjadi pokok prinsip yang menentukan obyek keistimewaaan pada ketentuan UU no 26 tahun 2007 mengenai pemanfaatan dan struktur tata ruang kota DIY ada beberapa obyek keistimewaan budaya pada tata ruang kota DIY yang dilihat pada bagian keseluruhan struktur ruang kota sebagai penanda keistimewaan dan ada sebagian pola ruang kota guna untuk symbol keistimewaan yaitu dapat dilihat sbb:

Tabel 1 dibawah ini merupakan beberpa symbol stuktur ruang kota sebagai penanda keistimewaan. 


\begin{tabular}{|c|c|c|}
\hline Cinsur & Penunda / Komponen & Uraian \\
\hline \multirow[t]{3}{*}{$\begin{array}{l}\text { Sitrukiut } \\
\text { Rume } \\
\text { kata }\end{array}$} & $\begin{array}{l}\text { Poros Tugu - Kraton - Pnngeung } \\
\text { Krapyak. } \\
\text { Bangunau carur sagotru. } \\
\text { - Loji Gedk, loji kebon, gereja. }\end{array}$ & 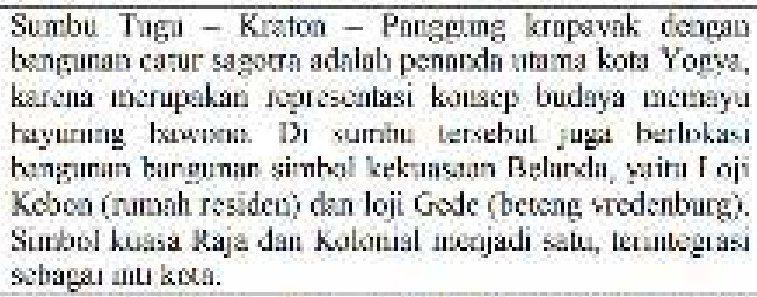 \\
\hline & $\begin{array}{l}\text { - Binganas tatur sagotra. } \\
\text { - Mesjut l'alhok Negaro. }\end{array}$ & 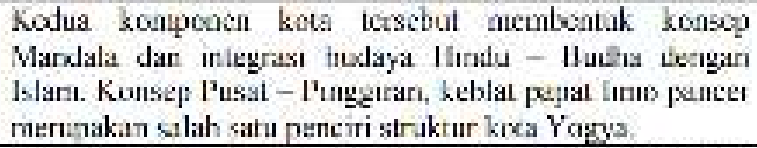 \\
\hline & $\begin{array}{l}\text { Konfigurasi sumba simetri dan } \\
\text { mandala. }\end{array}$ & 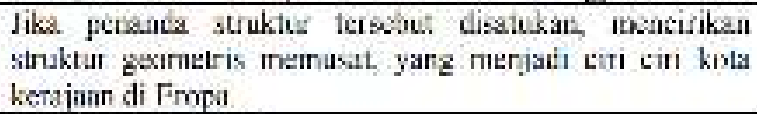 \\
\hline
\end{tabular}

Sumber : Suryanto, 2015

Table 2 dibawah ini merupakan beberpa symbol komponen pola tata ruang sebagai penanda keistimewaan.

\begin{tabular}{|c|c|c|}
\hline Insur & Penanda / Komponen & Iiraian \\
\hline \multirow[t]{2}{*}{$\begin{array}{l}\text { Pola } \\
\text { Ruang }\end{array}$} & $\begin{array}{l}\text { Kawasan kampang omiarit. } \\
\text { Kawssan Jerun Heleng. } \\
\text { Kawasan Pathol Neguma }\end{array}$ & 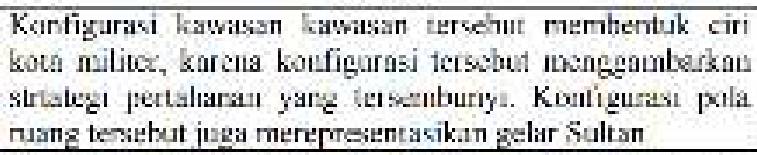 \\
\hline & $\begin{array}{l}\text { Kawasan Malishimo } \\
\text { - Kawasan Kampus ULiM }\end{array}$ & 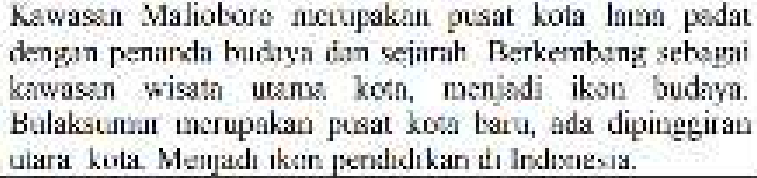 \\
\hline
\end{tabular}

Sumber : Suryato, 2015

Dalam hal ini penulis mengambil studi kasus menegenai jalan malioboro hal tersebut dilator belakangi dengan adanya buadaya yang sangan kental dalam proses ulang pebuatan jalan malioboro tersebut dapata di lihat struktur pembangnan nya seperti keterangan dibawah ini. Malioboro sebagai kawasan peninggalan sejarah memiliki aspek kebudayaan dalam pembuatan maupun pembenan pada pola ruangnya pada adapun peraturan yang harus dipatuhi dan harus selaras dengan peraturan jika akan membangun pertokohan, hotel, maupun yang lainya adapun bagian bagian yang di perbolehkan maupun tidak di perboleh. Pada hal ini bagian belakang/dalam harus lebih dari 60 (enam puluh) meter dari garis batas luar rumija / ruang milik jalan dan diperbolehkan untuk membangun bangunan yang lebih tinggi dari bangunan yang berada di depan bangunanya, dengan memebentuk sudut 45 (empat puluh lima derajat) dari ketinggian yang sudah di tentukan dan jika keinginan lain 
tersebut dikehendaki sudut pandang $45^{\circ}$ ( empat puluh lima derajat) harus ada persetujuan dari walikota Yogyakarta dengan maksimal ketinggian 32 (tigapuluh dua meter). Ini lah yang pada akhirnya membedakan daerah Istimewa Yogyakarata dari pada daerah lainya.

Kompleks yang berada pada jarak 60 meter dari Kawasan yng sudah di tentukan harus menyesuaikan dan memperhatikan keharmonisan dan karakter yang sejalan dengan tujuan dan haapan dari Kawasan perlindungan maupun inti dari citra kota sealain itu juga harus sejalan dengan dengan perkembangan bangunan malioboro, bangunan-bangunan yang memiliki arsitektur india, arsitektur cina maupun arsitektur colonial, sehingga bangunan-bangunan baru bisa tidak menenggelamkan maupun menghapus bangunan inti bangunan yang dilindungi budaya maupun maupun cagar budaya.

Menurut perdais no 2 tahun 2017 tentang pemanfaatan ruang yang di peroleh pada satuan strategis sumbu filosofi secara nyatanya di Yogyakarta belum di realisasikan secara konkrit karena pada kenyataanya banyak bangunan yang tingginya lebih dari 32 meter, hal ini dipahami karena pada saat pembuatan kebijakan bangunan tersebut sudah ada dan jadi, sehingga tidak bisa langsung diberikan sangsi. Contoh gambaran mengenai pembangunan yang benar sbb:

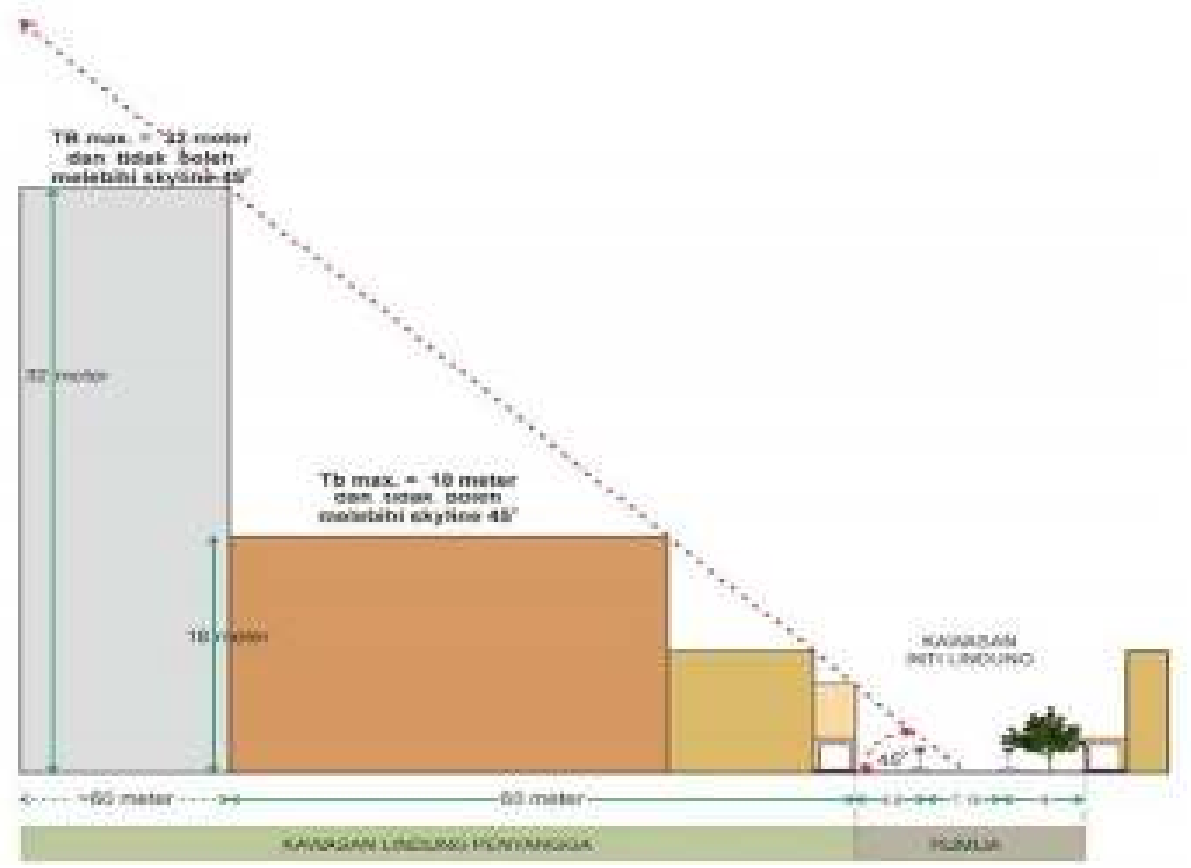


Adapun menurut "pasal 14 ayat 2 (a) mengenai pemanfaatan ruang yang tidak diperbolehkan pada satuan ruang strategis sumbu filososfi yang berbunyi membangun bangunan baru yang melintang di atas jalan pada Sumbu Filosofi" jadi dalam pemaknaan yang sebenarnya bahwasanya setiap ada bangunan baru yang di bangun dan melintang diatas jalan dan jalan tersebut memiliki folosofi atapun makna tertentu maka hal tersebut tidak dibenarkan dan sudah ada larangan mengenai hal ini. Selain itu jika ada seseorang yang akan membangun bangunan baru harus memiliki makna mengenai filosofi tentang bangunan yang akan di bangun di sepanjang daerah yang memiliki folosofi mengenai kebudayaan.

Selain itu ada juga mengenai pemanfaatan ruang yang tidak di perbolehkan pada satuan tata ruang strategis sumbu filosofi yakni pada pasal 14 ayat 2 (b) yang memiliki redaksi kata yaitu "membangun bangunan di kanan dan kiri Sumbu Filosofi dengan ketinggian yang akan mempengaruhi dan/atau menghilangkan nilai budaya Sumbu Filosofi" maksut dari pemaparan ini yaitu bangunan yang berada di kanan kiri yang memiliki makna filosofi serta bangunan yang tinggi akan memepengaruhi dan memudarkan budaya yang memiliki nilai sumbu filosofi. Selain menjelaskan mengenai kebijakan pemanfaatan ruang yang di perbolehkan pada satuan strategis sumbu filosofi penulis juga akan sedikit membahas mengenai pendanaan istimewa yang yang di berikan pemerintah pusat ke pada Daerah Istimeewa Yogyakarta.

Daerah Istimewa Yogyakarta sebagai daerah yang memiliki keistimewaan dalam beberapa hal juga memiliki keistimewaan dalam soal pendanaan. Dana keistimewaan adalah dana yang bersumber dari anggaran bagian bendahara umum negara yang pembagian perhitungan rencana penjatahan sumber daya bagi negara sebagai pendanaan wewenang istimewa Yogyakarta dan merupakan bagian pengalihan belanja untuk tranfer belanja. Pada dasarnya pendanaan yang ada di Daerah Istimewa Yogyakarta (DIY) memiliki aturan perundang-undangan yang di buat langsung oleh 
gubernur, yang sesuai dengan perturan gubernur Daerah Istimewa Yogyakarta nomor 23 tahun 2016 tentang pengelolaan dana keistimewaan.

Awal mula pengelolaan dana istimewa sudah diatur pada peraturan gubernur nomor 37 tahun 2014 tentang pengelolaan dana keistimewaan sebagaimana terakhir kalinya diubah dengan peraturan gubernur nomor 113 tahun 2015 mengenei berubahnya peraturan gubenrur Daerah Istimewa Yogyakarta nomor 37 tahun 2014 tentang pengelolaan dana keistimewaan. Dalam peraturan ini belumlah di jelaskan secara rinci mengenai mekanisme penetapan pejabat yang menjadi penatausaan keuangan oleh sebab itu gubernur membuat peraturan baru,

Pada dasarnya sampai saat ini pemerintah pusat masih menggelontorkan dana guna dana keistimewaan bagi DIY yang bermula pada tahun 2013 dan berlangsung hingga saat ini, dan hal ini tidaklah tau hingga sampai kapan dana perdais akan tetap di gelontorkan untuk Daerah Istimewa Yogyakarta dan penggelontoran dana perdais bisa berhenti sewaktu-waktu jika pemerintah pusat tidak mengizinkan dana tersebut turun, serta diawasi langsung oleh direktoran jenderal keuangan negara republic Indonesia oleh sebab itu akuntabilitas dana yang di gelontorkan harus masuk kepada masyarakat yang ada di Jogjakarta. Dana keistimewaan DIY dimanfaatkan untuk membiayai kewenangan tamabahan tertentu yang di miliki oleh DIY selain itu juga menentukan wewenang pada undang undang pemerintah daerah. Pembiyaan tersebut yaitu 1) "tata cara pengisian jabatan, kedudukan, tugas dan wewenang gubernur dan wakil gubernu”. 2) kelembagaa, dalam penggunaan danais Lembaga memiliki peran yang cukup penting sehingga memerlukan dana yang cukup banyak dalam pengembanganya. 3) kebudayaan, sebagai daerah wisata tentunya DIY memiliki kebudayaan yang memiliki potensi untuk menarik wisatawan, oleh sebab itu danan yang di gelontorkan untuk pengembangan budaya juga cukup banyak. 4) pertanahan dan tata ruang hal inilah yang perlu banyak akan anggaran untuk pembangunan-pembangunan daerah yang berada dikabupaten oleh sebab itu pemerintah pusat menganggarkan banyak mengenai untuk pembangunan infrastruktur yang berada di wilayah DIY, 
percepatan pertumbuhan pembangunan merupakan wujud dari cita cita bangsa indonesia yang sudah tertera dalam nawa cita.

Kewenangan istimewa yang didapatkan oleh Daerah Istimewa Yogyakarta yaitu adanya dana istimewa pada berbagaai urusan salah satunya urusan tata ruang. Menurut Mutiarin dan Skir (2014) menjelaskan bahwa dengan diberlakukan Undang Undang tersebut, diharapkan dapat memberikan kesejahteraan terhadap hak hak masyarakat dan dalam bentuk faktanya nyatanya masih belum berjalan dengan baik. Berbagai faktor faktor yang membuat hal tersebut terjadi diantaranya masih adanya pembangunan perkotaan yang tidak menuruti Undang Undang yang berlaku terutama bagi Peraturan Daerah Istimewa Yogyakarta yang sudah diperbaharui pada tahun 2017. Penataan ruang perkotaan di Yogyakarta menunjukkan bahwa masih adanya pembangunan yang tidak sesuai dengan peraturan tersebut diantaranya pembangunan mall dan hotel yang tidak teratur. Seperti Sleman city mall yang baru baru ini dibuka, menurut seksi penataan ruang Daerah Istimewa Yogyakarta berpendapat bahwa pembangunan tersebut menyalahi aturan yang ada, tetapi tidak ada cara lain selain dibangunnya mall tersebut karena sudah terlanjur dibangun setelah pertauran tersebut diresmikan. Pada tahun 2018 pembangunan pusat perbelanjanaan yang ada di Sleman yaitu Sleman City Mall telah dibuka dengan berbagai kontroversi, anak dari proyek PT Garuda Mitra yang menjadi pengelola Jogja City Mall tersebut dikabarkan telah menyalahi Peraturan Daerah. Pembangunan Mall tersebut telah diakui menyalahi peraturan daerah Nomor 2 Tahun 2015 mengenai pendirian pembangunan. Masalah perizinan yang diajukan hanya ssebatas lokasi bukan pemanfaatan tanah. Menurut seksi pemanfataan tata ruang Daerah Istimewa Yogyakarta menegaskan bahwa Sleman City Mall tersebut juga menyalahi Peraturan Daerah Istimewa Yogyakarta tentang sistim pembangunannya yang sseharusnya mall tersebut di bangun agak kebelakang agar pinggir jalan tidak terlalu terlihat padat.

c) Kasus Jalur Jalan Lintas Selatan (JJLS) DIY. 
Pembangunan Infrastruktur Jalur Jalan Lintas Selatan (JJLS) merupakan program Nasional yang yang melewati 5 provinsi yang ada di Pulau Jawa yang salah satu provinsi yang dilalui adalah Daerah Istimewa Yogyakarta. Salah satu Desa yang dilewati oleh pembangunan JJLS di Provinsi Daerah Istimewa Yogyakarta adalah Desa Gadingsari, Kecamatan Sanden, Kabupaten Bantul. Dampak dari pembangunan JJLS ini terhadap desa yang dilalui salah satunya adalah terjadinya perubahan penggunaan lahan disepanjang wilayah yang dilewati. Pada penelitian ini akan dilihat bagaimana perubahan penggunaan lahan di desa Gadingsari sebelum dan setelah JJLS. Tujuan penelitian ini adalah untuk menganalisis perubahan penggunaan lahan yang terjadi di Desa Gadingsari. Metode analisis yang digunakan adalah metode analisis deskriptif kualitatif. Perubahan penggunaan lahan didapatkan dari Analisis Overlay Citra Satelit dalam rentang waktu, yaitu sebelum JJLS dibangun tahun 2013 dan setelah JJLS dibangun pada tahun 2017 serta diperkuat dengan survey lapangan dan wawancara mendalam. Dari hasil penelitian di dapatkan bahwa luas lahan untuk pemukiman di Desa Gadingsari sebelum dan setelah adanya JJLS mengalami perubahan. Sebelum adanya JJLS luas lahan pemukiman 78.90 hektar dan bertambah luasnya menjadi 104.93 hektar setelah pembangunan JJLS, terjadi pertambahan luas sekitar 32.99 \%.. Proses pembangunan jalur jalan lintas selatan (JJLS) di wilayah DI Yogyakarta telah berlangsung sejak tahun 2005 dan kendala utamanya adalah proses pembebasan lahan yang menelan anggaran Rp 1,112 triliun untuk lahan seluas 2.492.325 meter persegi dengan total kebutuhan lahan untuk JJLS empat jalur mencapai 3.456.805 meter persegi. Kepala Bidang Bina Marga Dinas Pekerjaan Umum Energi dan Sumber Daya Mineral (DPU ESDM) DIY, Bambang Sugaib mengatakan, proyek yang dimulai sejak tahun 2005 ini awalnya menggunakan APBD Pemda DIY dan sharing dari APBD Kabupaten. "Pengeluaran anggaran pembebasan bisa diperbesar dimulai dari tahun 2014 sampai 2019. Karena pada saat itu sudah mulai dibiayai dengan dana keistimewaan," ujar Bambang Sugaib saat memaparkan progress JJLS di proyek LOT5 JJLS Jerukwudel-Baran-Duwet, Girisubo, 
Gunungkidul. Berikut gambar proyek JJLS yang akan digarap pemerintah DIY.

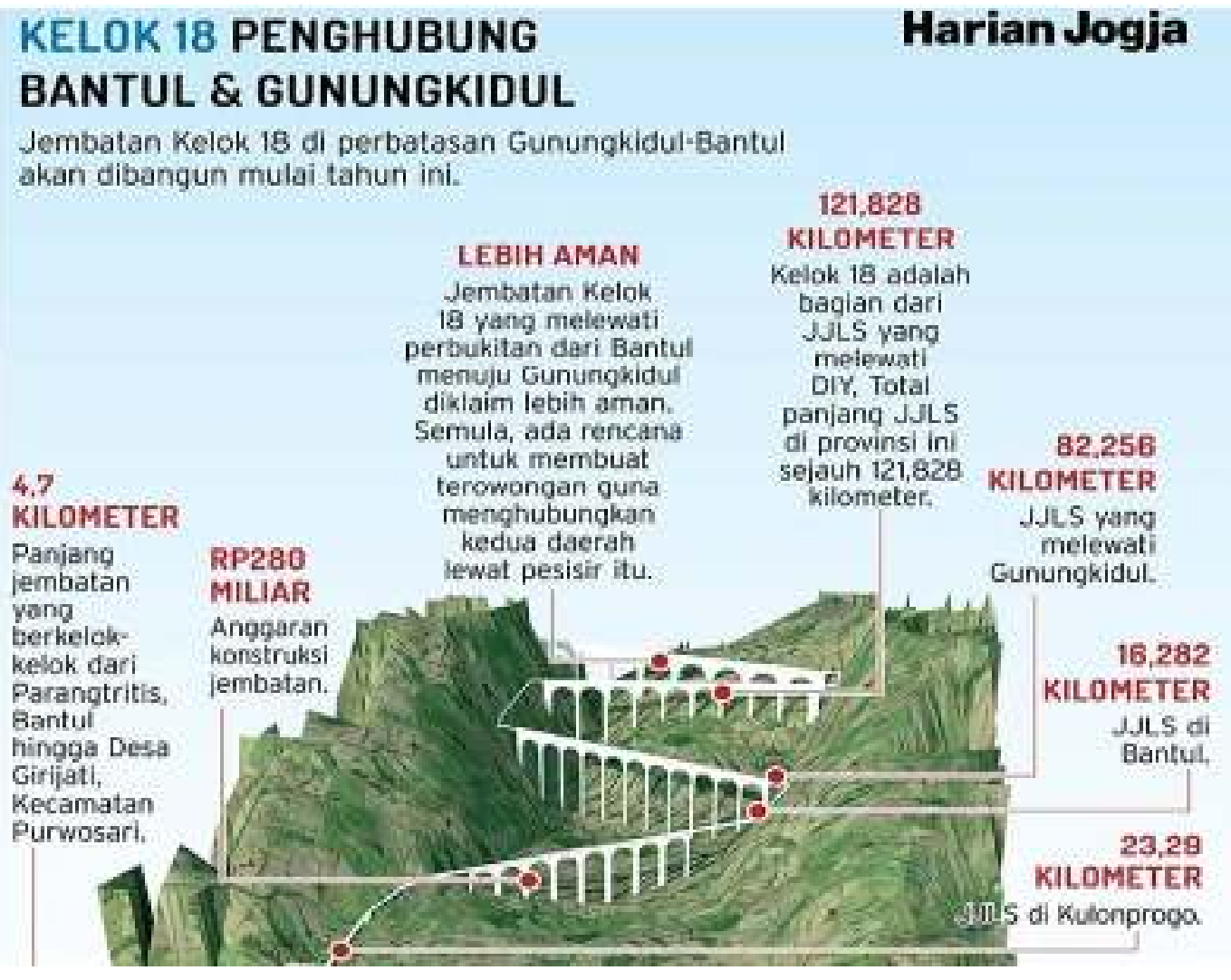

\section{Sumber : https://kusnantokarasan.com/tag/jils-bantul/}

Saat ini, pihaknya tengah merampungkan trase Jeruk Wudel-Duwet di perbatasan Gunungkidul-Wonogiri. Jalan sepanjang 10,6 kilometer tersebut dibuat empat lajur dengan total anggaran yang dialokasikan sebesar Rp 260 miliar. Untuk sementara ruas jalan TepusJerukwudel perkiraan kebutuhan tanah mencapai 250.402 meter persegi. JJLS merupakan jalur trans selatan Jawa yang melajur dari Jawa Barat hingga Jawa Timur dengan total panjang jalan 121,83 kilometer. JLSS di DIY terbagi di Kulonprogo dengan panjang 23,29 km, Bantul 16,28 km, dan Gunungkidul 82,26 km. Bambang Sugaib mengatakan, total 116 kilometer yang akan dibangun dari Kabupaten Kulonprogo menuju Gunungkidul, sudah lebih separuh dikerjakan, atau sudah mencapai 75 kilometer. Sementara, untuk ruas 
Ngremang-Garongan luas tanah yang akan dibebaskan mencapai 144.706 meter persegi, dengan perkiraan anggaran mencapai Rp 291 miliar. Ruas ini ditargetkan bisa diselesaikan pembebasan lahannya hingga tahun 2024 mendatang. Beberapa ruas lain yang dibebaskan adalah Garongan-Congot (137.772 meter persegi) dan ditargetkan dibebaskan pada tahun 2021, sedang ruas Legundi-Planjan (236.600 meter persegi) yang ditargetkan tahun 2022, serta, ruas Girijati-Legundi (195.000 meter persegi) dan ditargetkan selesai tahun 2024.

Selain proses pengadaan tanahnya dan pembangunannya cukup lama, karena faktor medan panjang, area perbukitan kapur dan batuan yang perlu waktu lama untuk perataan. "Medan yang cukup licin juga berpengaruh, termasuk perlunya identifikasi lahan milik ribuan warga yang memerlukan waktu lama untuk mengidentifikasi," ujarnya. Dia menyebutkan, untuk pembangunan konstruksi JJLS-nya dilakukan Pemerintah Pusat dalam hal ini Satuan Kerja (Satker) Perencanaan dan Pengawasan Jalan Nasional (P2JN) secara bertahap karena memang membutuhkan anggaran yang cukup besar. Bambang mengatakan, JJLS berfungsi sebagai akses utama yang dapat dihubungkan dengan akses lokal yang dibangun Pemkab setempat menuju kawasan wisata di sepanjang pantai, juga sebagai akses utama yang melintasi dan menghubungkan dengan kawasan wisata di sepanjang Pantai Selatan baik di Gunungkidul, Bantul hingga Kulonprogo. Sementara, project Officer Satuan Kerja Jalan Nasional Wilayah V, Juniar Perkasa mengungkapkan, pihaknya sudah memperhitungkan secara matang pembangunan JJLS. Rute jalan menghindari ronggarongga jalur air bawah tanah atau gua.

\section{KESIMPULAN}

Peraturan Derah Istimewa Yogyakarta Nomor 2 Tahun 2017 disebutkan bahwa keistimewaan dari Kota Yogyakarta yang lain yaitu terdapat satuan ruang strategis yaitu adanya Satuan Ruang Tanah Kadipaten dan Satuan Ruang Tanah Kadipaten. Pengelolaan tanah kadipaten dan tanah kasultananakan diserahkan ke administratif masing masing daerah dengan persetujuan Sultan dan Pakualaman. Nilai keistimewaan yang dimiliki oleh Kota Yogyakaarta baik awasan tanah kasultanan dan tanah kadipaten maupun satuan ruang yang lainnya akan diprioritaskan Pemerintah Daerah bagaimana caranya kawasan satuan ruang tersebut digunakan secara 
makssimal sesuai dengan Peraturan Daerah Istimewa. Pemrioritasan kawasan satuan ruang tersebut akan berpengaruh terhadap budaya, kelestarian lingkungan, serta kepentingan sosial. Penataan ruang Keistimewaan Daerah Istimewa Yogyakarta merupakan salah satu dari sistem proses perencanaan dan penataan Tata Ruang maupun pengendalian pemanfaatan kawasan satuan strategis tersebut.

Kebijakan yang dilakukan dari dinas tataruang Daerah Istimewa Yogyakarta berfokus pada membuat landasan landasan peraturan yang terkait dengan pemanfaatan ruang di satuan ruang strategis. Mengingat bahwa Peraturan Daerah Nomor 2 Tahun 2010 mengenai dengan RTRW DIY tahun 20092029 dianggap sudah tidak relevan dengan situasi di DIY, oleh karena itu Peraturan Derah harus seceptnya diganti dengan membandingkan kondisi yang sedang dihadapi wilayah DIY. Menurut Qoyin sebagai seksi pengaturan tataruang Daerah Istimewa Yogyakarta menjelaskan bahwa "Banyak Dinamika dilapangan yang terjadi sejak Perda No. 2 Tahun 2010 diundangkan, sehingga terjadi perubahan yang tidak sesuai lagi dengan konten. Peraturan Daerah dan aturan tersebut dapat mengisyaratkan jika perubahan konten lebih dari 20\% maka perlu dibuat Perda yang baru".

Kewenangan istimewa yang didapatkan oleh Daerah Istimewa Yogyakarta yaitu adanya dana istimewa pada berbagaai urusan salah satunya urusan tata ruang. Menurut Mutiarin dan Skir (2014) menjelaskan bahwa dengan diberlakukan Undang Undang tersebut, diharapkan dapat memberikan kesejahteraan terhadap hak hak masyarakat dan dalam bentuk faktanya nyatanya masih belum berjalan dengan baik. Berbagai faktor faktor yang membuat hal tersebut terjadi diantaranya masih adanya pembangunan perkotaan yang tidak menuruti Undang Undang yang berlaku terutama bagi Peraturan Daerah Istimewa Yogyakarta yang sudah diperbaharui pada tahun 2017. Penataan ruang perkotaan di Yogyakarta menunjukkan bahwa masih adanya pembangunan yang tidak sesuai dengan peraturan tersebut diantaranya pembangunan mall dan hotel yang tidak teratur. Seperti Sleman city mall yang baru baru ini dibuka, menurut seksi penataan ruang Daerah Istimewa Yogyakarta berpendapat bahwa pembangunan tersebut 
menyalahi aturan yang ada, tetapi tidak ada cara lain selain dibangunnya mall tersebut karena sudah terlanjur dibangun setelah pertauran tersebut diresmikan.

\section{DAFTAR PUSTAKA}

Ariyanti, V., Sjamsinarsi, I. R., \& Wicaksono, A. A. (2013). The Sermo Dam Experience, Indonesia Community Development as Key Success for Dam Project Implementation and Operation.

Bank Dunia. (2014). Kesenjangan di Indonesia: Tren, Penyebab, Kebijakan. Jakarta: Bank Dunia.

Clammer, J. (1996). Values and Development in Southeast Asia. Michigan: Pelanduk Publications.

Dixon, W. J., \& Modd, A. M. (2013). The Statistical Sign Test. Journal of the American Statistical Association, 41(236), 557-566.

Florida, Richard. (2017). Canada's New Urban Crisis. Toronto.

Hardiansah, E. C. (2015). Pengantar Edisi Khusus 55 Tahun Pendidikan Planologi: Pembangunan Kota Inklusif di Era Desentralisasi, 26(1), 1-6.

Nadarajah, M., \& Yamamoto, A. T. (Eds.). (2006). Urban Crisis Culture and the Sustainability of Cities. New York: United Nation University Press.

Resosudarmo, B. P., \& Thorbecke, E. (1996). The Impact of Environmental Policies on Household Incomes for Different Socio-Economic Classes: The Case of Air Pollutants in Indonesia. Ecological Economics, 17(2), 8394.

Sholikhah, M., Suratman, B., Soesatyo, Y., \& Soejoto, A. (2014). Analisis Faktor Yang Memengaruhi Ketimpangan Pendidikan. Jurnal Ilmu Pendidikan, 2O(20), 176-182.

Suryanto. (2015). "Keistimewaan Tata Ruang Yogyakarta". Yogyakarta: Disertasi.

Todaro, M., \& Smith, S. C. (2011). Pembangunan Ekonomi: Edisi Kesebelas. Jakarta: Erlangga.

Udkhiyah, R., Kristian, G., \& Adlan, C. A. (2012). Analisis Sistem Informasi Geografis Statistik Logistik Biner dalam Upaya Pengendalian Ekspansi Lahan Terbangun Kota Yogyakarta. 52-58. 
Wayan, N., Piramida, L., Sari, E., Pujianiki, N. N., Bagus, I., \& Purbawijaya, N. (2014). Persepsi Masyarakat Terhadap Implementasi Undang-Undang Pengelolaan Wilayah Pesisir (Studi Kasus: Pantai Sanur, Denpasar). Jurnal Teknik Sipil, 15-21. 